\title{
Embriogenesis Somatik dari Eksplan Benih Gandum Tropis (Triticum aestivum L.)
}

\author{
Somatic Embryogenesis in Seed Explant of Tropical Wheat (Triticum aestivum L.) \\ Endang Pudjihartati* dan Maria Marina Herawati
}

Fakultas Pertanian, Universitas Kristen Satya Wacana Salatiga, Jln. Diponegoro 55-60 Salatiga

E-mail: endangeps@staff.uksw.edu *Penulis untuk korespondensi

\begin{abstract}
Somatic embryogenesis of tropical wheat, Dewata variety and two wheat lines collection of the Wheat Studies Center, SWCU Agriculture and Business Faculty, namely R-036 and R-040, were investigated using mature embryos (seeds) as explants. These studies consists of the embryogenic callus induction and proliferation phase, to obtain tropical wheat genotypes that can be cultured in vitro and the best medium in order to get somatic embryos (SE). In induction phase, the wheat seeds explants were cultured on four concentrations of $2,4-d(2 ; 2.5 ; 3$ and 3.5 ppm). Four compositions media containing 2.5 and 3 ppm 2,4-D with and without 0.5 ppm BAP has been studied for proliferation phase. The results showed that the number of primary $S E$ and SE score relatively high on the Dewata variety at $3 \mathrm{ppm}$ 2,4-d, the R-040 line at $2.5 \mathrm{ppm}$ 2,4-d, and R-036 line at $2 \mathrm{ppm}$ 2.4-d. The R-036 wheat line produces the number of primary $\mathrm{SE}$ and SE scores are relatively high compared to the other genotypes. The quality of seeds affect explant response to the primary SE and SE scores and less affect to the number of secondary ES and ES score. In the proliferation phase, the relatively highest number of secondary ES, from R036 line at $2.5 \mathrm{ppm}$ 2,4-d, while the Dewata variety and R-040 at $2.5 \mathrm{ppm}$ and $3.0 \mathrm{ppm}$ 2,4-d, respectively. Application of 2,4-d with BAP decrease the number of SE, but only small decrease the secondary ES scores on three genotypes. The maximum secondary SE score of R-036 line at 2.5 ppm 2.4 - $\mathrm{d}$ but there was no influence PGR compositions studied (2,4-D and BAP) to the SE scores proliferation on Dewata variety and R-040 line.
\end{abstract}

Keywords: Tropical wheat, callus induction, proliferation, 2.4-d, BAP

Abstrak

Embriogenesis somatik dalam penelitian ini menggunakan eksplan embrio dewasa (benih) gandum tropis varietas Dewata dan galur R-036 dan R-040 koleksi Pusat Studi Gandum Fakultas Pertanian dan Bisnis UKSW, meliputi tahap induksi dan proliferasi. Penelitian ini bertujuan mendapatkan genotipe gandum tropis yang mudah di kultur secara in vitro dan medium yang baik dalam rangka memperoleh Embrio Somatik (ES). Pada tahap induksi, benih gandum dikultur pada empat konsentrasi 2,4-d (2; 2,5; 3 dan 3,5 ppm). Pada tahap proliferasi diteliti empat komposisi media yang mengandung 2,5 dan 3 ppm 2,4-d dengan dan tanpa 0,5 ppm BAP. Hasil penelitian menunjukkan bahwa jumlah ES dan skor ES primer relatif tertinggi dari varietas Dewata pada 3 ppm 2,4-d, galur R-040 pada 2,5 ppm 2,4-d, dan galur R-036 pada 2 ppm 2,4-d. Eksplan gandum galur R-036 menghasilkan jumlah ES dan skor ES primer relatif tertinggi dibandingkan genotipe lain. Mutu benih yang digunakan mempengaruhi respons eksplan dalam menghasilkan jumlah ES dan skor ES primer dan kurang mempengaruhi jumlah ES dan skor ES sekunder. Pada tahap proliferasi, jumlah ES sekunder relatif tertinggi, dari galur R-036 pada 2,5 ppm 2,4-d, sedangkan varietas Dewata dan R-040 berturut-turut pada 2,5 ppm dan 3,0 ppm 2,4-d. Aplikasi 2,4-d yang dikombinasikan dengan BAP dapat menurunkan jumlah ES, tetapi hanya cenderung menurunkan skor ES sekunder pada ketiga genotipe. Pada skor ES hasil proliferasi tidak diamati adanya pengaruh komposisi ZPT yang diteliti (2,4-d dan BAP) pada varietas Dewata dan galur R-040, sedangkan pada galur R-036 skor ES sekunder maksimum pada 2,5 ppm 2,4-d.

Kata kunci: Gandum tropis, induksi kalus, proliferasi, 2,4-d, BAP 